\title{
REKAYASA ULANG PROSES BISNIS \\ REGISTRASI PENGISIAN KRS ONLINE PORTAL AKADEMIK UNIVERSITAS SAM RATULANGI
}

\author{
Stanley Karouw ${ }^{1}$, Reskyana Tanggo ${ }^{2}$, Sheila Claudy Riady ${ }^{3}$ \\ 1,2,3, Program Studi Teknik Informatika, Fakultas Teknik, Universitas Sam Ratulangi \\ Jl. Kampus UNSRAT Bahu, 95115 \\ ${ }^{1}$ stanley.karouw@unsrat.ac.id, ${ }^{2}$ kikiana_03@yahoo.com, ${ }^{3}$ sheilariady9@gmail.com
}

\begin{abstract}
Abstrak
Universitas Sam Ratulangi (UNSRAT) adalah salah satu Perguruan Tinggi Negeri (PTN) unggulan yang ada di Sulawesi Utara. Sejak tahun 2009, UNSRAT telah mengimplementasikan Sistem Informasi Terpadu (SIT), dimana salah satu modulnya adalah Portal Akademik yang berfungsi untuk mengelola proses registrasi pengisian Kartu Rencana Studi (KRS) secara online. Pada paper ini kami akan menyajikan rekayasa ulang proses bisnis registrasi pengisian KRS Online di Portal Akademik UNSRAT dengan menggunakan metode BPR (Business Process Reengineering). Proses bisnis pengisian KRS Online Portal Akademik diawali dengan identifikasi aktivitas dan dilanjutkan dengan membuat model proses bisnis menggunakan Business Process Notation Model (BPM)N. Hasil yang didapatkan adalah gambar model bisnis proses dan rancangan bisnis proses hasil rekayasa ulang.
\end{abstract}

Kata kunci : Bisnis Proses, Rekayasa Ulang, Sistem Informasi

\section{Pendahuluan}

Universitas Sam Ratulangi (UNSRAT) Manado merupakan salah satu universitas negeri unggulan yang ada di provinsi Sulawesi Utara. Sejak 14 September 1965 UNSRAT telah ditetapkan sebagai Perguruan Tinggi Negeri (PTN) dengan tujuh fakultas.[1]. Seiring perkembangan zaman, maka UNSRAT pun terus mengembangkan diri untuk menjadi salah satu pusat keunggulan di kawasan Indonesia Timur.

UNSRAT terus berusaha meningkatkan kinerjanya dalam pengelolaan pendidikan tinggi. Implementasi Sistem Informasi Terpadu (disingkat SIT) oleh UNSRAT merupakan salah satu upaya untuk mewujudkan visi UNSRAT, yakni Menjadi Universitas yang Excellent[2]. SIT UNSRAT diharapkan untuk memudahkan pengelolaan proses bisnis akademik pendidikan tinggi. Kemudahan pengelolaan ini dapat membuat setiap stakeholder, terlebih mahasiswa merasa nyaman, terutama dalam proses pengisian KRS, yang rutin dilakukan setiap awal semester baru. Proses pengisian KRS merupakan salah satu fungsionalitas utama dari Modul Portal Akademik, yang merupakan modul yang terintegrasi dengan SIT UNSRAT.

Permasalahan yang sering terjadi dalam proses pengisian KRS secara manual adalah waktu yang terlalu lama, dan sering terjadi kesalahan entry data oleh pihak-pihak pengguna. Paper ini memaparkan identifikasi aktivitas pengisian registrasi KRS, pemodelan proses bisnis dan rekayasa-ulang proses bisnis registrasi pengisian KRS Online di Portal Akademik UNSRAT. Tujuan yang ingin dicapai adalah meningkatkan tingkat efisiensi proses bisnis registrasi pengisian KRS Online.

Rekayasa ulang proses bisnis dimaksudkan untuk memberikan solusi terkait permasalahan tersebut diatas, yakni mempercepat waktu pengisian KRS dan mengurangi kesalahan entry. Model proses bisnis dibangun dengan menggunakan kakas BPMN. Model proses bisnis registrasi mahasiswa diharapkan dapat memberikan deskrpsi yang lengkap dan mendetail terkait aktivitas registrasi sehingga dari model tersebut dapat dilakukan rekayasa-ulang proses bisnis.

\section{Dasar Teori}

\subsection{Kerangka Penelitian}

Kerangka penelitian selengkapnya dapat dilihat pada Gambar 1. Kerangka penelitian terdiri dari tiga langkah utama:

1) Analisa Konteks dan Ruang Lingkup; dimana pada tahap ini dilakukan pengumpulan data. Data dikumpulkan dengan melakukan studi literatur, melakukan wawancara dan menyebarkan 
kuesioner. Studi literatur berupa dokumendokumen yang terkait perundang-undangan tentang Pendidikan Tinggi, dokumen tentang UNSRAT serta dokumen lainnya yang terkait. Wawancara dan kuesioner dilakukan pada pemangku kepentingan dalam lingkungan UNSRAT, seperti pimpinan manajemen utama, menengah dan pelaksana.

2) Identifikasi Proses Bisnis. Tahap kedua adalah melakukan kajian proses bisnis admisi (atau proses penerimaan calon mahasiswa baru). Proses bisnis disusun berdasarkan urutan peristiwa (atau aktivitas) beserta aktor yang terkait atau berperan pada peristiwa dan akativitas tersebut. Setelah itu, proses bisnis direkonstruksi kembali, dengan mempertimbangkan masukan dari pimpinan.

3) Pemodelan Proses Bisnis. Tahap ketiga ini merupakan langkah terakhir, yakni proses bisnis yang telah direkonstruksi ulang, dimodelkan dengan menggunakan kakas Business Process Notation Model versi 1.0 (BPMN).

4) Melakukan rekayasa-ulang proses bisnis dengan panduan peta ASME.

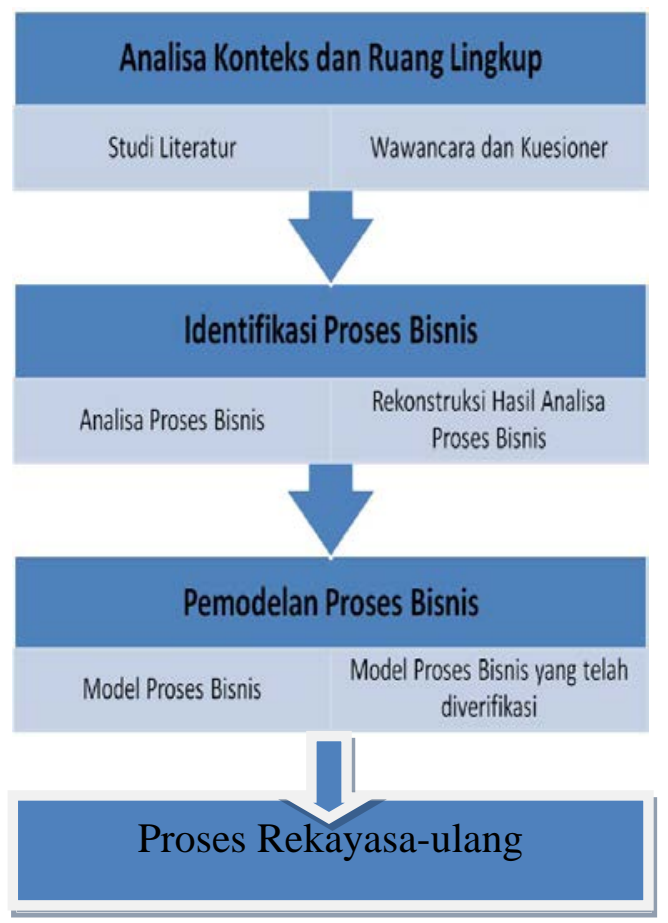

Gambar 1 Kerangka Penelitian

\subsection{BPMN}

BPMN[3] adalah singkatan dari Business Process Modeling Notation, yaitu suatu metodologi baru yang dikembangkan oleh Business Process Modeling Initiative sebagai suatu standard baru pada pemodelan proses bisnis, dan juga sebagai alat desain pada sistem yang kompleks seperti sistem eBusiness yang berbasis pesan (message-based).[4]
Tujuan utama dari BPMN adalah menyediakan notasi yang mudah digunakan dan bisa dimengerti oleh semua orang yang terlibat dalam bisnis, yang meliputi bisnis analis yang memodelkan proses bisnis, pengembang teknik yang membangun sistem yang melaksanakan bisnis, dan berbagai tingkatan manajemen yang harus dapat membaca dan memahami proses diagram dengan cepat sehingga dapat membantu dalam pengambilan keputusan.[4]

\subsection{Rekayasa Ulang Bisnis Proses}

Menurut Alan Dennis et.al[5], Business Process Reengineering atau rekayasa ulang proses bisnis merupakan metode perbaikan yang radikal dan mendasar pada proses-proses bisnis, guna mencapai perbaikan yang dramatis. Prinsip kerja ini sangatlah berbeda dengan metode continuous improvement, karena konsep ini menganggap bahwa proses yang digunakan saat ini sudah tidak relevan lagi sehingga proses tersebut harus dibuang dan diganti dengan proses yang sama sekali baru. Meskipun demikian, terdapat resiko yang tinggi dan terkadang membutuhkan biaya yang cukup besar.

Salah satu cara yang paling efektif untuk memahami proses yang ada adalah dengan membuat bagan proses pada sebuah peta standar American Society of Mechanical Engineers (ASME).[6]

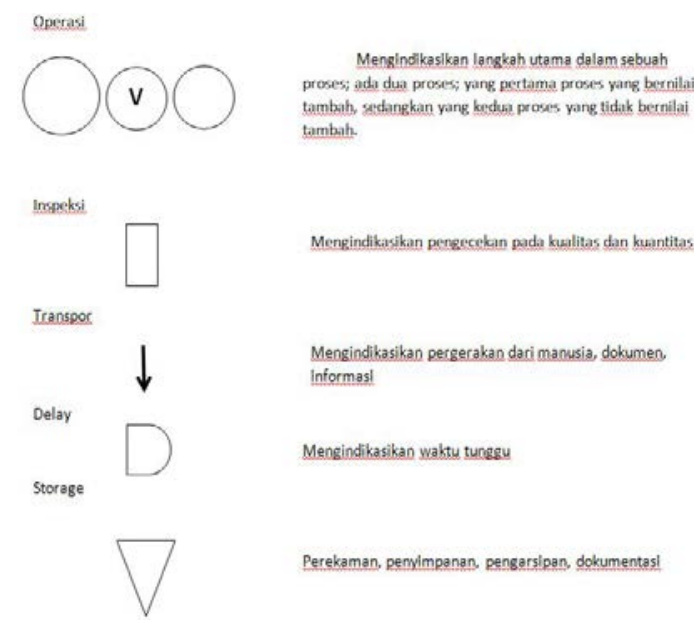

Gambar 2. Simbol-simbol Tabel ASME

\section{Pembahasan}

\subsection{Analisa Konteks dan Ruang Lingkup}

Pada tahap ini, dilakukan analisa konteks, yakni dibatasi bahwa proses bisnis yang akan dianalisa terkait Modul Portal Akademik yang ada pada Sistem Informasi Terpadu (SIT) UNSRAT. Proses bisnis pengisian KRS Online merupakan bagian dari modul Portal Akademik.

\subsection{Identifikasi Proses Bisnis}

Identifikasi proses bisnis[7] dilakukan dengan mengumpulkan data, dengan menggunakan teknik wawancara, kuesioner dan pengamatan langsung. 
Berdasarkan data-data yang diperoleh, maka disusunlah proses pengisian KRS secara manual sebagai berikut:

1) Membayar SPP. Para mahasiswa diwajibkan untuk membayar SPP terlebih dahulu. Setelah membayar SPP, mahasiswa diminta untuk melkukan registrasi pada pihak Fakultas. Registrasi ini dilakukan dengan cara memberikan bukti pembayaran SPP (dalam bentuk struk pembayaran dari Bank).

2) Mengambil kertas pengisian KRS. Tiap mahasiswa wajib mengambil kertas yang telah disediakan di kantor jurusan untuk mengisi KRS.

3) Pihak kantor jurusan memberikan kertas pengisian KRS.

4) Membuka portal akademik. Tiap mahasiswa telah diberikan Username yang berupa NRI dan password (ditentukan sendiri) untuk mengakses portal akademik untuk kelancaran proses pengisian KRS.

5) Memasukkan username dan password. Mahasiswa harus mengisi username dan password untuk dapat membuka portal dan mengisi KRS.

6) Mengecek mata kuliah yang ditawarkan. Setelah membuka portal, tiap mahasiswa membuka menu informasi mata kuliah yang ditawarkan, sesuai dengan semester yang sedang berjalan.

7) Mengisi KRS. Pengisian KRS ini bisa dilakukan jika mahasiswa telah memperoleh Kartu Hasil Studi (KHS) semester sebelumnya (untuk mahasiswa lama). Berdasarkan Indeks Prestasi (IP) yang didapat jumlah SKS dapat ditentukan. Mahasiswa akan mengisi KRS berdasarkan data dari informasi matakuliah yang ditawarkan.

8) Menghubungi dosen pembimbing. Setelah mengisi KRS, maka mahasiswa akan menghubungi dosen pembimbing, dan dosen pembimbing akan memeriksa KRS tersebut.

9) Jika dosen pembimbing telah menyetujui pengisian KRS tersebut, pada saat kita mengakses portal akademik akan ada info bahwa KRS yang kita masukkan telah disetujui, dan dosen pembimbing akan menandatangani kertas KRS tersebut.

10) Jika belum disetujui, maka mahasiswa harus segera menghubungi dosen pembimbing. Karena sebelum dosen pembimbing menyetujui KRS, nama mahasiswa yang bersangkutan nantinya tidak akan terdaftar dalam kelas yang telah dipihnya, atau jika dosen pembimbing tidak menyetujui pengisian KRS tersebut, maka mahasiswa harus segera melakukan revisi KRS tersebut.

11) Menunggu proses pengisian KRS Online. Setelah mengisi KRS secara manual, mahasiswa juga diwajibkan untuk melakukan pengisian KRS secara Online dengan memasukkan data KRS manual.

Sedangkan untuk proses bisnis pengisian KRS secara online menggunakan Portal Akademik, aktivitasnya adalah sebagai berikut:

1. Membayar SPP. Para mahasiswa diwajibkan untuk membayar SPP terlebih dahulu. Setelah membayar SPP, mahasiswa diminta untuk melakukan registrasi pada pihak Fakultas. Registrasi ini dilakukan dengan cara memberikan bukti pembayaran SPP (dalam bentuk slip pembayaran dari Bank).

2. Membuka portal akademik. Tiap mahasiswa telah diberikan Username yang berupa NRI dan password (ditentukan sendiri) untuk mengakses portal akademik untuk kelancaran proses pengisian KRS.

3. Memasukkan username dan password. Mahasiswa harus mengisi username dan password untuk dapat membuka portal dan mengisi KRS.

4. Memilih kartu rencana studi. Setelah membuka portal, mahasiswa akan memilih Kartu Rencana Studi pada menu Academic.

5. Mengisi KRS. Pengisian KRS ini bisa dilakukan jika mahasiswa telah memperoleh Kartu Hasil Studi (KHS) semester sebelumnya (mahasiswa lama). Berdasarkan Indeks Prestasi (IP) yang didapat jumlah SKS dapat ditentukan.

6. Proses pemilihan kelas dan dosen pengampu. Dalam proses pemilihan kelas dan dosen pengampu, ada angkatan yang penempatan kelasnya diatur secara otomatis dan ada yang dipilih secara manual.

- Jika kelas yang dipilih belum penuh, mahasiswa bisa mengontrak kelas tersebut

- Jika kelas yang dipilih sudah penuh, mahasiswa harus mencari dan mengontrak kelas lain yang belum penuh.

7. Menghubungi dosen pembimbing. Setelah mengisi KRS, kita harus memastikan apakah dosen pembimbing telah menyetujui pengisian KRS tersebut.

- Jika dosen pembimbing telah menyetujui pengisian KRS tersebut, pada saat kita mengakses portal akademik adakn ada info bahwa KRS yang kita masukkan telah disetujui.

- Jika belum disetujui, maka mahasiswa harus segera menghubungi dosen pembimbing. Karena sebelum dosen pembimbing menyetujui KRS, nama mahasiswa yang bersangkutan nantinya tidak akan terdaftar dalam kelas yang telah dipihnya.

8. Mencetak KRS. Setelah KRS telah disetujui oleh dosen pembimbing, maka KRS dapat dicetak.

9. Dosen pembimbing menandatangani KRS.

10. Pembantu dekan I menandatangani KRS 
11. Kantor jurusan menerima selembar KRS yang telah ditandatangani sebagai arsip Fakultas.

12. Mahasiswa menyimpan selembar KRS yang telah ditandatangani sebagai bukti

\subsection{Pemodelan Proses Bisnis}

Pemodelan proses bisnis dilakukan dengan menggunakan BPMN. Panduan untuk menggambar proses bisnis dengan BPMN mengacu pada standar yang dipublikasikan oleh OMG[8][9]. Model proses bisnis Pengisian Registrasi KRS Online dapat dilihat pada Gambar 3 (dapat dilihat pada bagian akhir dari paper ini).

\subsection{Proses Rekayasa-ulang}

Berdasarkan hasil analisis pada proses pengisian KRS Online Fakultas Teknik Universitas Sam Ratulangi kami telah membuat tahap-tahap dalam proses pengisian KRS tersebut. Tahap-tahapnya sebagai berikut:

1) Membuka portal akademik. Tiap mahasiswa telah diberikan Username yang berupa NRI dan password (ditentukan sendiri) untuk mengakses portal akademik untuk kelancaran proses pengisian KRS. (waktu yang diperlukan 0,083 menit)

2) Memasukkan username dan password. Mahasiswa harus mengisi username dan password untuk dapat membuka portal dan mengisi KRS. (waktu yang diperlukan 0,15 menit)

3) Mengecek dan memilih Kartu rencana strudi pada menu academics (waktu yang diperlukan 0,016 menit)

4) Menekan menu tambah mata kuliah (waktu yang diperlukan 0,016 menit)

5) Memilih dan mencentang mata kuliah beserta kelas lalu tekan pilihan simpan (waktu yang diperlukan 3 menit)

6) Menghubungi dosen pembimbing. Setelah mengisi KRS, kita harus memastikan apakah dosen pembimbing telah menyetujui pengisian KRS tersebut. (waktu yang diperlukan 50400 menit)

7) Jika dosen pembimbing telah menyetujui pengisian KRS tersebut, pada saat kita mengakses portal akademik adakn ada info bahwa KRS yang kita masukkan telah disetujui.

8) Jika belum disetujui, maka mahasiswa harus segera menghubungi dosen pembimbing. Karena sebelum dosen pembimbing menyetujui KRS, nama mahasiswa yang bersangkutan nantinya tidak akan terdaftar dalam kelas yang telah dipihnya.

9) Mencetak KRS. Setelah KRS telah disetujui oleh dosen pembimbing, maka KRS dapat dicetak. (waktu yang diperlukan 2 menit)
10) Dosen pembimbing dan wakil dekan 1 menandatangani KRS. (waktu yang diperlukan 2 menit)

11) Menunggu Penandatanganan KRS (waktu yang diperlukan 2 menit)

12) Kantor jurusan menerima selembar KRS yang telah ditandatangani sebagai arsip Fakultas. (waktu yang diperlukan 5 menit)

13) Mahasiswa menyimpan selembar KRS yang telah ditandatangani sebagai bukti (waktu yang diperlukan 1 menit)

Total waktu yang diperlukan untuk keseluruhan proses bisnis ini adalah 50415,3 menit.

Sedangkan untuk rekayasa ulang proses bisnis diatas, langkah-langkahnya adalah sebagai berikut:

1. Membuka portal akademik. Tiap mahasiswa telah diberikan Username yang berupa NRI dan password (ditentukan sendiri) untuk mengakses portal akademik untuk kelancaran proses pengisian KRS. (waktu yang diperlukan 0,083 menit)

2. Memasukkan username dan password. Mahasiswa harus mengisi username dan password untuk dapat membuka portal dan mengisi KRS. (waktu yang diperlukan 0,15 menit)

3. Mengecek dan memilih Kartu rencana strudi pada menu academics (waktu yang diperlukan 0,016 menit)

4. Menekan menu tambah mata kuliah (waktu yang diperlukan 0,016 menit)

5. Memilih dan mencentang mata kuliah beserta kelas lalu tekan pilihan simpan (waktu yang diperlukan 3 menit)

6. Secara otomatis permintaan pengisian KRS akan ditangani oleh sistem. (waktu yang diperlukan 1 menit)

7. Mencetak KRS. Setelah KRS telah disetujui oleh dosen pembimbing, maka KRS dapat dicetak. (waktu yang diperlukan 2 menit)

8. Dosen pembimbing dan wakil dekan 1 menandatangani KRS. (waktu yang diperlukan 2 menit)

9. Menunggu Penandatanganan KRS (waktu yang diperlukan 2 menit)

10. Kantor jurusan menerima selembar KRS yang telah ditandatangani sebagai arsip Fakultas. (waktu yang diperlukan 5 menit)

11. Mahasiswa menyimpan selembar KRS yang telah ditandatangani sebagai bukti

(waktu yang diperlukan 1 menit)

Total waktu yang diperlukan adalah 16,3 menit. Jika dibandingkan waktu yang diperlukan, sebelum dan sesudah langkah2 tersebut direkayasa-ulang, maka terdapat selisih 50399 menit.

Dari kedua langkah-langkah diatas bisa kita lihat perbedaan waktu yang besar antara pengunaan waktu sebelum dan sesudah langkah-langkah tersebut direkayasa yaitu 50415,3 menit dan 16,3 
menit. Dengan selisih 50399 menit. (lihat Gambar 4).

\section{Kesimpulan}

Terdapat beberapa kesimpulan yang bisa diperoleh dari pembahasan ini, yakni:

1) Pengisian KRS secara manual bisa dikatakan lebih rumit, sehingga membutuhkan waktu relative lebih lama. Hal ini dikarenakan dalam mengisi KRS manual, mahasiswa harus melihat terlebih dahulu tentang informasi mata kuliah yang ditawarkan, beban SKS, serta kelas yang nantinya akan dikontrak. (Pada langkah ke-6 dalam proses pengisian KRS manual)

2) BPMN dapat digunakan untuk membuat model proses bisnis. BPMN dapat memodelkan proses bisnis dengan lebih efisien dan lebih terperinci.

3) Proses penyetujuan pengisian KRS oleh dosen pembimbing bisa dikatakan kurang efisien dalam hal penggunaan waktu. Hal ini dikarenakan mahasiswa harus menghubungi dosen pembimbing yang bersangkutan dan menunggu waktu ampai KRS tersebut disetujui.

4) Proses penyetujuan pengisian KRS dengan menggunakan sistem lebih efektif dan lebih menghemat waktu. (berdasarkan pengukuran waktu yang telah dilakukan sebelumnya, yaitu langkah-langkah sebelum rekayasa ulang yaitu 50415,3 menit dan setelah direkayasa ulang 16,3 menit. Dengan selisih 50399 menit)

5) BPR pemodelan proses pengisian KRS bisa lebih efisien dan lebih menghemat waktu

\section{Daftar Pustaka:}

[1] Tim Penyusun, "Buku Panduan Akademik Tahun 2012/2013 Fakultas Teknik Universitas Sam Ratulangi" , Manado, 2012

[2] Tim Penyusun, Buku Profil Universitas Sam Ratulangi Manado Tahun 2013”, Manado, 2013

[3] Object Management Group, "Business Process Model and Notation (BPMN)”, OMG Document Number: formal/2011-01-04, 2011.

[4] Sutono, BUSINESS PROCESS REENGINEERING STUDI KASUS PT, diakses di: http://www.scribd.com/doc/134830280/unggah-pdf, pada 7 Desember 2013.

[5] Alan Dennis, et al, "System Analysis and Desing with UML $4^{\text {th }}$ Edition”, John Wiley and Sons, 2013.

[6] Website Resmi ASME ....., diakses pada

[7] Stanley Karouw, Tanggo Kykyana dan Riady Sheila, "Proses Bisnis Registrasi Pengisian KRS Manual dan Online Fakultas Teknik Universita Sam Ratulangi”, Proceedings Seminar Nasional I Think Smart UNKLAB, 2013.

[8] Object Management Group, "Business Process Modelling Notation, V1.1”, OMG Document Number: formal/2008-01-17, Januari 2008.
[9] Object Management Group, "BPMN 2.0 by Example”, OMG Document Number: dtc/2010-0602, 2011. 


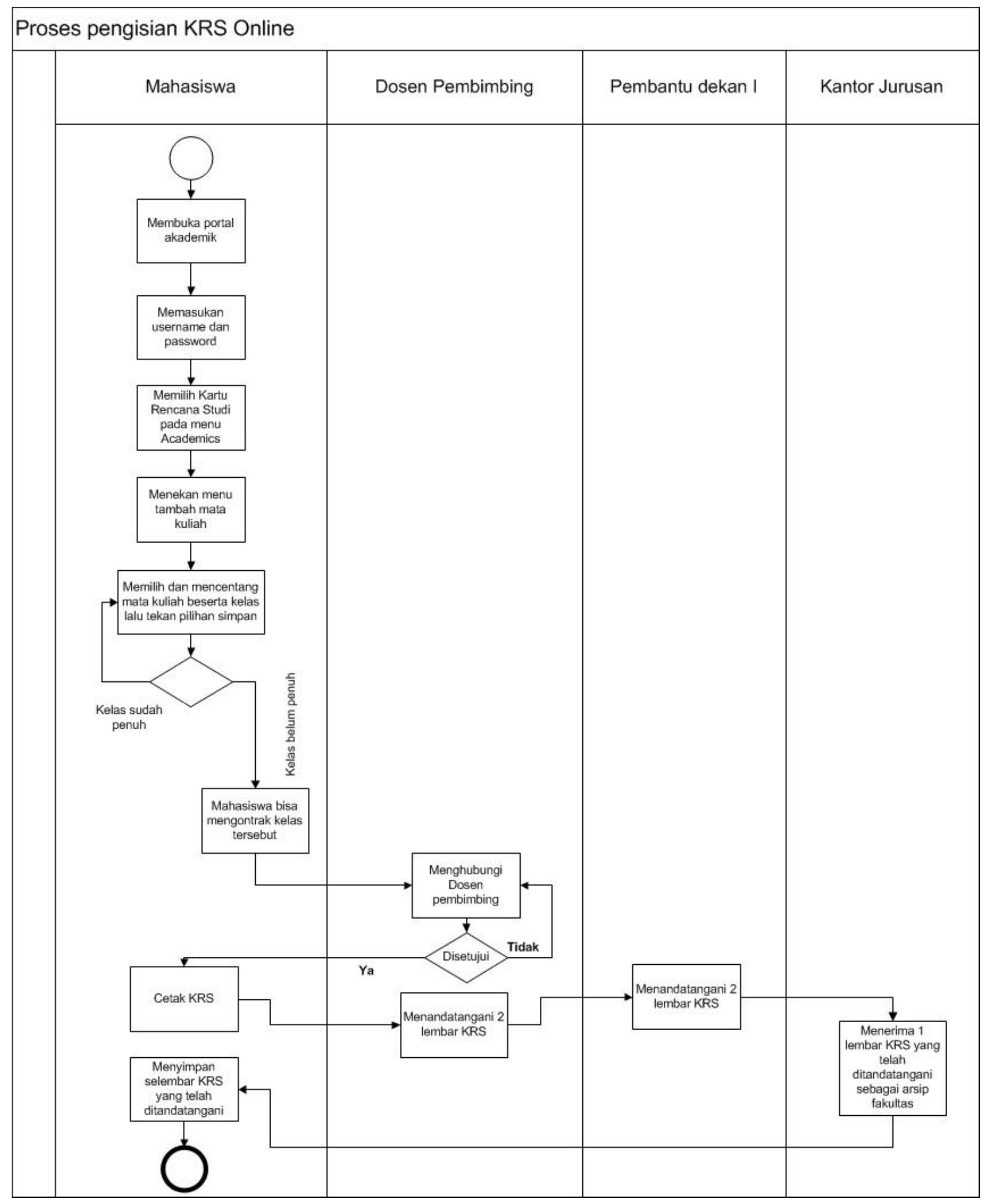

Gambar 3 Model Proses Bisnis Registrasi KRS Online dengan BPMN 


\begin{tabular}{|c|c|c|c|c|c|c|c|c|c|}
\hline No & Tahap Proses & (v) & O & $\square$ & $\rightarrow$ & D & $\nabla$ & Waktul & $\begin{array}{l}\text { Pemilik } \\
\text { Proses }\end{array}$ \\
\hline 1 & $\begin{array}{c}\text { Membukk Portal } \\
\text { Akademik }\end{array}$ & & & & & & & $\begin{array}{l}0,083 \\
\text { menit } \\
\end{array}$ & Mhs \\
\hline 2 & $\begin{array}{l}\text { Memasukkan } \\
\text { user name dan } \\
\text { password }\end{array}$ & & & & & & & \begin{tabular}{c|}
0,15 \\
menit \\
\end{tabular} & Mhs \\
\hline 3 & $\begin{array}{l}\text { Mengeceek dan } \\
\text { memilh Kartu } \\
\text { rencana strudi } \\
\text { pada menu } \\
\text { academics }\end{array}$ & & & & & & & \begin{tabular}{l|}
0,016 \\
menit \\
\end{tabular} & Mhs \\
\hline 4 & $\begin{array}{c}\text { Menekan menu } \\
\text { tambah mata } \\
\text { kuliah }\end{array}$ & & & & & & & $\begin{array}{l}0,016 \\
\text { menit } \\
\end{array}$ & Mhs \\
\hline 5 & 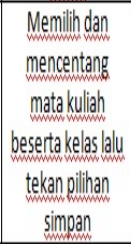 & & & & & & & 3 menit & Mhs \\
\hline 6 & $\begin{array}{l}\text { Dihubungioleh } \\
\text { mahasiswa untuk } \\
\text { menvetujui KRS }\end{array}$ & & & & & & & $\begin{array}{l}50400 \\
\text { menit } \\
\end{array}$ & $\begin{array}{c}\text { Dosen } \\
\text { pembimbing }\end{array}$ \\
\hline 7 & Cetak KRS & & & & & & & 2 menit & Mhs \\
\hline 8 & \begin{tabular}{|l} 
Menandatangani \\
2lembar KRS
\end{tabular} & & & & & & & 2 menit & $\begin{array}{c}\text { Dosen } \\
\text { Pembimbing } \\
\text { Wakildekan } \\
1 \\
\end{array}$ \\
\hline 9 & $\begin{array}{c}\text { Menunggu } \\
\text { Penandatanganan } \\
\text { KRS }\end{array}$ & & & & & 0 & & 2 menit & Mhs \\
\hline 10 & $\begin{array}{c}\text { Menerimalembar } \\
\text { KRS yang } \\
\text { ditandatangani } \\
\text { sebaraga arsip } \\
\text { fakultas }\end{array}$ & & & & & & 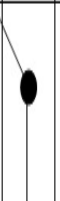 & 5 menit & $\begin{array}{l}\text { Kantor } \\
\text { Jurusan }\end{array}$ \\
\hline 11 & $\begin{array}{c}\text { Menyimpan } \\
\text { lembar KRS yang } \\
\text { telah } \\
\text { ditandatangani } \\
\end{array}$ & & & & & & 0 & 1 menit & Mhs \\
\hline & Jumlah Tahap & 1 & 1 & 1 & 5 & 1 & 2 & 11 & \\
\hline & Total Waktu & $\begin{array}{c}2 \\
\text { menit }\end{array}$ & \begin{tabular}{|c|}
3 \\
menit: \\
\end{tabular} & \begin{tabular}{|l|}
0,016 \\
menit
\end{tabular} & $\begin{array}{l}50402,3 \\
\text { menit }\end{array}$ & $\begin{array}{c}2 \\
\text { menit }\end{array}$ & \begin{tabular}{|c|}
6 \\
menit \\
\end{tabular} & $\begin{array}{c}50415,3 \\
\text { menit } \\
\end{array}$ & \\
\hline
\end{tabular}

\begin{tabular}{|c|c|c|c|c|c|c|c|c|c|}
\hline No & Tahap Proses & (v) & 0 & $\square$ & $\rightarrow$ & D & $\nabla$ & Waktul & $\begin{array}{l}\text { Pemilik } \\
\text { Proses }\end{array}$ \\
\hline 1 & $\begin{array}{c}\text { Membukk Portal } \\
\text { Akademik }\end{array}$ & & & & A & & & $\begin{array}{l}0,083 \\
\text { menit }\end{array}$ & Mhs \\
\hline 2 & $\begin{array}{l}\text { Memasukkan } \\
\text { user name dan } \\
\text { password }\end{array}$ & & & & & & & $\begin{array}{l}0,15 \\
\text { menit }\end{array}$ & Mhs \\
\hline 3 & $\begin{array}{l}\text { Mengecek dan } \\
\text { memilh Kartu } \\
\text { rencena strudi } \\
\text { pada menu } \\
\text { academics }\end{array}$ & & & & & & & $\begin{array}{l}0,016 \\
\text { menit }\end{array}$ & Mhs \\
\hline 4 & $\begin{array}{c}\text { Menekan menu } \\
\text { tambah mata } \\
\text { kuliah }\end{array}$ & & & & & & & $\begin{array}{l}0,016 \\
\text { menit }\end{array}$ & Mhs \\
\hline 5 & 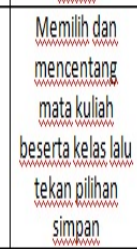 & & & & & & & 3 menit & Mhs \\
\hline 6 & $\begin{array}{l}\text { Menungegu } \\
\text { pernerimaan } \\
\text { pengajuan KRS }\end{array}$ & & & & & & & 1 ment & $\begin{array}{l}\text { Sistem porta } \\
\text { akademik }\end{array}$ \\
\hline 7 & CetakKRS & & & & & & & 2 menit & Mhs \\
\hline 8 & $\begin{array}{c}\text { Menandatangani } \\
\text { 2lembar KRS }\end{array}$ & & & & & & & 2 menit & $\begin{array}{c}\text { Dosen } \\
\text { Pembimbing } \\
\text { Wakil dekan } \\
1\end{array}$ \\
\hline 9 & $\begin{array}{c}\text { Menunggu } \\
\text { Penandatanganan } \\
\text { KRS }\end{array}$ & & & & & a & & 2 menit & Mhs \\
\hline 10 & $\begin{array}{c}\text { Menerimalembar" } \\
\text { KRS yang } \\
\text { dittandatangani } \\
\text { sebagra arsio } \\
\text { fakultas }\end{array}$ & & & & & & 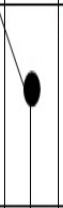 & 5 menit & $\begin{array}{l}\text { Kantor } \\
\text { Jurusan }\end{array}$ \\
\hline 11 & $\begin{array}{c}\text { Menvimpan } \\
\text { lembark KRS yang } \\
\text { telah } \\
\text { ditandatangani } \\
\end{array}$ & & & & & & 0 & 1 menit & Mhs \\
\hline & Jumlah Tahap & 1 & 1 & 1 & 5 & 1 & 2 & 11 & \\
\hline & Total Waktu & $\begin{array}{c}2 \\
\text { menit } \\
\end{array}$ & $\begin{array}{c}3 \\
\text { menit } \\
\end{array}$ & \begin{tabular}{|l|}
0,016 \\
menit \\
\end{tabular} & \begin{tabular}{|l|}
3.3 \\
menit
\end{tabular} & $\begin{array}{c}2 \\
\text { menit } \\
\end{array}$ & \begin{tabular}{|c|}
6 \\
menit \\
manit
\end{tabular} & $\begin{array}{c}16,3 \\
\text { menit } \\
\end{array}$ & \\
\hline
\end{tabular}

Gambar 4 Proses Bisnis Pengisian KRS Online (sebelah kiri) dan Proses Bisnis Pengisian KRS Online yang telah direkayasa-ulang (sebelah kanan) 